\title{
Intoxication Due to High Dose Methotrexate in a Patient with Rheumatoid Arthritis: A Case Report
}

\author{
Romatoid Artritli Bir Hastada Yüksek Doz Metotreksat Kullanımına Bağlı Toksisite: \\ Olgu Sunumu
}

\author{
Özlem ALTINDAĞ, Birsev KÜÇÜKOĞLU \\ Department of Physical Medicine and Rehabilitation, Medical Faculty of Gaziantep University, Gaziantep, Turkey
}

\begin{abstract}
Methotrexate is an antimetabolite which impairs deoxyribonucleic acid (DNA) synthesis by competitively inhibiting folic acid metabolism. Methotrexate is successfully used in the treatment of neoplastic diseases as well as rheumatoid arthritis. Long-term use of methotrexate is quite safe and very effective in the treatment of rheumatoid arthritis. However, it may rarely cause severe side effects such as myelosupression with pancytopenia to agranulocytosis; inflammation and necrotic changes in mucosal tissues; liver cell necrosis and hepatic cirrhosis; pulmonary fibrosis and impairment in kidney functions. In this article, we report a 52-year-old female with a case of leukopenia and febrile neutropenia due to methotrexate intoxication that resulted from an accidental overdose. Although methotrexate is usually well tolerated, it may still cause unexpected and lifethreatening intoxications. Methotrexate intoxication should be considered with the presence of high fever, severe nausea, vomiting, abdominal pain, diarrhea or oral ulcers in a patient diagnosed with rheumatoid arthritis.
\end{abstract}

Key words: Calcium folinate; methotrexate; overdose.

Methotrexate (MTX) is a folic acid antagonist which reduces the level of tetrahydrofolate in cells by inhibiting dihidrofolate reductase enzyme. Through this mechanism, it blocks the synthesis of timidilate required for deoxyribonucleic acid (DNA) ${ }^{[1]}$ Methotrexate can be used in high doses in the treatment of many malignant diseases together with other cytostatic drugs used as anticancer agents.
Metotreksat folik asit metabolizmasını kompetitif olarak inhibe ederek deoksiribonükleik asit (DNA) sentezinde bozulmaya neden olan bir antimetabolittir. Metotreksat, neoplastik hastalıkların tedavisinde ve aynı zamanda romatoid artrit tedavisinde başarıyla kullanılmaktadır. Romatoid artrit tedavisinde uzun süreli metotreksat kullanımı oldukça etkili ve güvenlidir. Ancak, nadiren, agranulositoz için pansitopeni ile kemik iliği baskılanması, mukoza dokularında inflamasyon ve nekrotik değişiklikler, karaciğer hücresi nekrozu ve hepatik siroz, akciğer fibrozu ve böbrek fonksiyon bozuklukları gibi şiddetli yan etkilere neden olabilmektedir. Bu yazıda yanlışlıkla aşırı doz metotreksat kullanan ve buna bağlı lökopeni ve febril nötropeni gelişen 52 yaşında bir kadın olgu sunuldu. Metotreksat genellikle iyi tolere edilirse de beklenmeyen ve hayatı tehdit edebilecek entoksikasyona neden olabilir. Romatoid artrit tanısı konulmuş olan bir hastada yüksek ateş, şiddetli bulantı, kusma, karın ağrısı, ishal veya oral ülserler görüldüğünde metotreksat entoksikasyonu akla gelmelidir.

Anahtar sözcükler: Kalsiyum folinat; metotreksat; doz aşımı.

Low doses of MTX are used in the treatment of inflammatory diseases such as rheumatoid arthritis (RA). It is the first choice among most physicians since it has a low activity/toxicity ratio and is considered an essential drug. ${ }^{[2]}$ Usually the effectiveness of newly developed treatment agents is evaluated with comparative studies to MTX, and these agents are often combined with MTX. The dose of MTX varies

Received: July 3, 2008 Accepted: August 18, 2008

Correspondence: Özlem Altındağ, M.D. Gaziantep Üniversitesi Tıp Fakültesi Fiziksel Tıp ve Rehabilitasyon Anabilim Dalı, 27070 Gaziantep, Turkey.

Tel: +90 342 - 3606060 / 11 e-mail: ozaltindag@yahoo.com

(C2011 Turkish League Against Rheumatism. All rights reserved. 
between $30-100 \mathrm{mg} / \mathrm{m}^{2}$ and the recommended weekly dose is $5-25 \mathrm{mg}$ in RA.

The drug cessation rates due to ineffectiveness or side effects have been reported between 10-30\%. Toxicity may occur in low-dose MTX; however, it is usually related to a long duration of treatment and high doses. ${ }^{[3]}$ Bone myelosuppression, pancytopenia, agranulocytosis, inflammation and necrotic changes in mucous tissues, liver cell necrosis and hepatic cirrhosis, pulmonary fibrosis, disorders of kidney function, vasculitis and skin lesions are some side effects that may occur during the use of MTX..$^{[1]}$ When MTX is used in high doses, calcium folinate is the recommended rescue therapy.

In this article, we report a patient with RA who had been given MTX in excess of the recommended dose. The patient was admitted to the emergency unit with oral ulcers, diarrhea, vomiting, fever and developed febrile neutropenia.

\section{CASE REPORT}

A 52-year-old female patient with a diagnosis of RA for two years was admitted to Gaziantep University Research Hospital. Her complaints were ongoing nausea and vomiting for two days, diarrhea with blood and mucus, abdominal pain and fever. Right upper quadrant tenderness and painful ulcers on the oral mucosa was detected on physical examination. Fever was $39{ }^{\circ} \mathrm{C}$ and arterial blood pressure was 140/90 mmHg. The results of the blood tests were: white blood cells $2990 / \mu \mathrm{L}$, neutrophils $2300 / \mu \mathrm{L}$, hemoglobin $8 \mathrm{~g} / \mathrm{dl}$, C-reactive protein $107 \mathrm{mg} / \mathrm{l}$, urea $58 \mathrm{mg} / \mathrm{dl}$, creatinine $1.6 \mathrm{mg} / \mathrm{dl}$, erythrocyte sedimentation rate $48 \mathrm{~mm} / \mathrm{h}$, ALT $450 \mathrm{U} / \mathrm{L}$, AST 687 U/L. Plenty of leukocytes and erythrocytes were detected on urine analysis. A review of her history revealed that $50 \mathrm{mg}$ intramuscular methotrexate injections had been administered twice to the patient on alternate days. We could not measure the blood levels of MTX because of insufficient laboratory conditions in our hospital. However, the patient had received approximately 10 times the recommended dose of MTX, and her complaints and blood tests indicated MTX intoxication. Repeated blood tests showed that the neutrophil count was $1800 / \mu \mathrm{L}$.

For treatment, $15 \mathrm{mg}$ calcium folinate in 5\% dextrose solution was intravenously infused four times a day for five days. The high fever was thought to be associated with neutropenia and broad-spectrum antibiotic (Ciprofloxacin $750 \mathrm{mg} \times 2 /$ day) treatment was given. The diarrhea, vomiting and oral ulcers disappeared. Blood tests showed a white blood cell count of $5300 / \mu \mathrm{L}$ and neutrophil of count $3300 / \mu \mathrm{L}$ with ALT: $50 \mathrm{U} / \mathrm{L}$ and AST: $56 \mathrm{U} / \mathrm{L}$.

On the $5^{\text {th }}$ day of calcium folinate treatment, blood test results and clinical findings had returned to normal levels. The treatment of RA of the patient was revised as follows: MTX $15 \mathrm{mg} /$ week, folic acid $5 \mathrm{mg} /$ week, prednisolone $4 \mathrm{mg} /$ day and salazopyrine $2 \mathrm{~g} /$ day, and she was discharged from hospital. No complaint was detected during a control examination one month later.

\section{DISCUSSION}

Methotrexate is an antimetabolite which impairs DNA synthesis by competitively inhibiting folic acid metabolism. ${ }^{[4]}$ It is difficult not to mention the importance of MTX in the current treatment of rheumatic diseases especially RA. It has been used in cancer treatment due to its antiproliferative effect for 50 years and as a disease-modifying drug in the treatment of RA for 20 years. After the start of treatment, it shows its effect within 3-6 weeks and is usually well tolerated. Methotrexate toxicity is often dose-dependent. Bone marrow toxicity is one of the most serious side effects, and this may occur even at low doses.

Usually, MTX treatments start with low doses to prevent toxicity and these can be increased until desired clinical effects are obtained. Despite a lack of clear evidence about lung toxicity of MTX, a chest X-ray is usually recommended before starting MTX treatment. Mucocutaneous side effects may start with mild oral ulcers and progress to serious esophageal, bladder and vaginal ulcers. Liver toxicity is seen less with drug use of less than once a week. Flu-like symptoms such as fever, chills, and muscle pain may occur during MTX treatment. ${ }^{[5]}$

In a 60 month long-term follow-up of $420 \mathrm{RA}$ patients treated with MTX, hematological toxicity occurred in 10 patients (2.4\%) (6 leukopenia, 3 thrombocytopenia and 1 pancytopenia). ${ }^{[3]}$ In another study, 284 RA patients treated with MTX were followed up for a mean of 33.2 months ${ }^{[6]}$ In this study 14 patients (4.9\%) had gastrointestinal side effects, nine patients (3.1\%) had increased liver enzymes, six patients (2.1\%) had interstitial pneumonia and four patients (1.4\%) developed pancytopenia.

Nadir and Şencan ${ }^{[5]}$ have reported a case of febrile neutropenia and pancytopenia that developed during MTX treatment ( $7.5 \mathrm{mg} /$ week, for 3 years). In our case the recommended dose was $20 \mathrm{mg} /$ week, but $50 \mathrm{mg} /$ day had been given by mistake at the pharmacy. Although 
the recommended dose for RA treatment may have been correct in our case, the overdose and related toxicity were not only the mistake of the pharmacist, but also a result of the physicians inadequately informing the patient.

Moisa et al. ${ }^{[1]}$ reported four fatal cases due to liver necrosis, pancytopenia and mucositis during the use of high-dose MTX and emphasized that physicians must be aware of possible fatal side effects of MTX.

A case of acute renal failure during MTX treatment $\left(3 \mathrm{~g} / \mathrm{m}^{2}\right)$ of cerebral lymphoma and its successful treatment with leucovorin and thymidine has been reported. ${ }^{[7]}$

In the present case, positive clinical and laboratory effects of calcium folinate emerged by the third day of treatment. Our case supports the use of calcium folinate as an effective treatment option for MTX toxicity.

Finally, patients should be adequately informed about the possible toxic effects of MTX when it is prescribed because many patients cannot communicate with their physicians after that time. Physicians should be accessible for patients. Under positive conditions, this drug can be effectively used, and possible side effects and economic losses may be prevented.

\section{Declaration of conflicting interests}

The authors declared no conflicts of interest with respect to the authorship and/or publication of this article.

\section{Funding}

The authors received no financial support for the research and/or authorship of this article.

\section{REFERENCES}

1. Moisa A, Fritz P, Benz D, Wehner HD. Iatrogenicallyrelated, fatal methotrexate intoxication: a series of four cases. Forensic Sci Int 2006;156:154-7.

2. Seçkin Ü, Borman P, Bodur H, Han Ö, Gön B. Romatoid artritli bir olguda metotreksat tedavisini bağlı hızlanmış nodül gelişimi. Turk J Rheumatol 2000;15:137-40.

3. Ohosone Y, Okano Y, Kameda H, Hama N, Matsumura M, Nojima T, et al. Toxicity of low-dose methotrexate in rheumatoid arthritis-clinical characteristics in patients with MTX-induced pancytopenia and interstitial pneumonitis. Ryumachi 1997;37:16-23. [Abstract]

4. Abu-Shakra M, Nicol P, Urowitz MB. Accelerated nodulosis, pleural effusion, and pericardial tamponade during methotrexate therapy. J Rheumatol 1994; 21:934-7.

5. Nadir I, Şencan M. Düşük doz metotreksat'a bağlı pansitopeni gelişen romatoid artrit olgusu. C. Ü. Tip Fakültesi Dergisi 2002;24:81-2.

6. Nakazaki S, Murayama T, Katoh S. Cytopenia associated with low dose pulse methotrexate in the treatment of rheumatoid arthritis. Ryumachi 2001;41:929-37. [Abstract]

7. van den Bongard HJ, Mathît RA, Boogerd W, Schornagel JH, Soesan M, Schellens JH, et al. Successful rescue with leucovorin and thymidine in a patient with highdose methotrexate induced acute renal failure. Cancer Chemother Pharmacol 2001;47:537-40. 